\title{
ACS SYMPOSIUM ON \\ METAL-CARBOXYLATE PROTEINS \\ AND SYNTHETIC MODELS
}

\section{To be held at Anaheim, CA, USA \\ April 2-5, 1995 \\ Co-organizers: \\ Don Kurtz and Karl Hagen \\ TENTATIVE PROGRAM:}

Sunday a.m. Tutorial:

8:45 - Introductory Remarks

Karl Hagen and Don Kurtz

9:00 - Carboxylate ligation in metalloproteins and the carboxylate shift

Steve Lippard

9:45 - Overexpression and site-directed mutations of non-heme iron proteins, or

Don Kurtz

The synthetic analogue approach

10:30 - Mössbauer spectroscopy of non-heme iron proteins

11:15 - Saturation magnetization of metal complexes and proteins

Vince Huynh

Tad Day

Sunday p.m.:

1:30 - Diiron oxo/hydroxo proteins. An overview of spectroscopy and structure, or Vibrational spectroscopy of diiron and dimanganese proteins and models

2:10 - Iron-carboxylate complexes

2:50 - New, biologically relevant metal-carboxylate complexes

3:30 - ENDOR and ESEEM of diiron proteins

4:10 - Magnetization of diiron(II) complexes and proteins

Tom Loehr
Karl Hagen
Steve Lippard
Brian Hoffman
Tad Day

Monday p.m.:

1:30 - Crystal and molecular structures of ribonucleotide reductase and rubrerythrin

2:10 - Crystal and molecular structure of methane monooxygenase

2:50 - Mechanisms of $\mathrm{O}_{2}$ reactions with the diiron sites in ribonucleotide reductase and methane monoxygenase

3:30 - $\mathrm{O}_{2}$ activation by iron complexes

4:10 - Fatty acid desaturases

4:50 - Rubrerythrin

Tuesday p.m.:

1:30 - Polyiron-oxo aggregates

2:10 - Metal loading of ferritin and bacterioferritin

2:50 - Manganese-carboxylate clusters

3:30 - Manganese catalase and synthetic models

4:10 - Arginase

Wednesday a.m.:

8:30 - Acid phosphatases

9:10 - Urease

9:50 - Phospholipase C

10:30 - Dimetal aminopeptidases

11:10 - Chromium-carboxylates and glucose tolerance factor
Pär Nordlund Amy Rosenzwieg

Vince Huynh

Larry Que, Jr.

Brian Fox

Don Kurtz

Annie K. Powell

Ed Stiefel

George Christou

Chuck Dismukes

David Ash

Bernt Krebs

Andy Karplus

Li-June Ming

Richard Holz

John Vincence

More information can be obtained from:

Dr. Don Kurtz

Professor of Chemistry and Biochemistry

University of Georgia, USA 